\title{
Primary Small Cell Neuroendocrine Carcinoma of Vagina: A Rare Case Report
}

\author{
Jignasa N. Bhalodia, ${ }^{1}$ Dhiren V. Kapapura, ${ }^{2}$ and Malay N. Parekh ${ }^{2}$ \\ ${ }^{1}$ Department of Pathology, GMERES Medical College Sola, B-37, Marutinandan Vihar Bungalows, Near Aarohi Villa, \\ S.P. Ring Road, Bopal, Ahmedabad 380058, India \\ ${ }^{2}$ Department of Pathology, C.U. Shah Medical College \& Hospital, Surendranagar 363001, Gujarat, India
}

Correspondence should be addressed to Jignasa N. Bhalodia, jignasanb@yahoo.co.in

Received 1 February 2011; Revised 26 July 2011; Accepted 30 July 2011

Academic Editor: Helmut Denk

Copyright (C 2011 Jignasa N. Bhalodia et al. This is an open access article distributed under the Creative Commons Attribution License, which permits unrestricted use, distribution, and reproduction in any medium, provided the original work is properly cited.

Primary small cell neuroendocrine carcinoma of vagina is an extremely rare disease. There have been only 26 previously reported cases in literature. Here, we report a case of primary small cell neuroendocrine carcinoma of vagina. Immunohistochemistry (IHC) showed tumor cells positive for synaptophysin, chromogranin, and neuron-specific enolase (NSE).

\section{Introduction}

Only five percent of small cell carcinomas arise in extra pulmonary sites [1], accounting for one to two percent of gynecological malignancies $[1,2]$. These tumors have been reported to originate in the cervix, endometrium, ovary, vagina, and vulva in decreasing frequency $[1,3,4]$. Primary small cell neuroendocrine carcinomas of vagina are rare, only 26 cases have been reported in English literature [1]. They have histological, ultrastructural, and immunohistochemical features similar to small cell carcinoma reported elsewhere in the body and in female genital tract $[1,3-5]$. They have an aggressive clinical behavior and a very poor prognosis even with current therapeutic modalities [3-5].

\section{Case History}

Fifty-year-old woman was admitted to hospital with complains of difficulty in urination and feeling of lump in anterior part of vagina since last six months. There was no significant past history and family history. Physical examination of external genitalia shows urethral carbuncle. On per vaginal examination, firm to hard mass was felt in the anterior vaginal wall. There was no evidence of ulceration, bleeding, discharge, or side wall involvement by tumor. On per speculum examination, cervix was normal. On transvaginal sonography, mass measuring $1.5 \times 1 \mathrm{~cm}$ arising from anterior vaginal wall was detected. Chest X-ray and ultrasonography of the abdomen and pelvis were normal. The patient underwent lump resection, and specimen was submitted for histopathology examination. We received single greyish white globular mass measuring $1.8 \times 1.8 \mathrm{~cm}$. Cut section was homogenous greyish white without any areas of hemorrhage or necrosis (Figure 1). On microscopic examination, section shows diffuse infiltration of small darkly stained cells arranged in ill-defined nest and trabeculae (Figure 2). The cells show fine granular powdery chromatin, inconspicuous nucleoli, and very scanty cytoplasm (Figure 3 ). Immunohistochemistry confirmed neuroendocrine origin by positivity for synaptophysin (Figure 4), chromogranin (Figure 5), and neuron-specific enolase (NSE) (Figure 6).

\section{Discussion}

Primary small cell neuroendocrine carcinoma of the lower genital tract of the female was first documented in 1972 by Albores-Saavedra et al. and diagnosed as carcinoid of the uterine cervix $[5,6]$. Primary small cell neuroendocrine carcinoma of the vagina, first reported in 1984 by Scully et al., is a rare neoplasm with only 26 reported cases in English literature to date $[1,4,6]$. Occurrence of this tumor is common in postmenopausal females [2]. These lesions have propensity for early, widespread dissemination [3]. Regardless of the extent of disease at present, most patients 


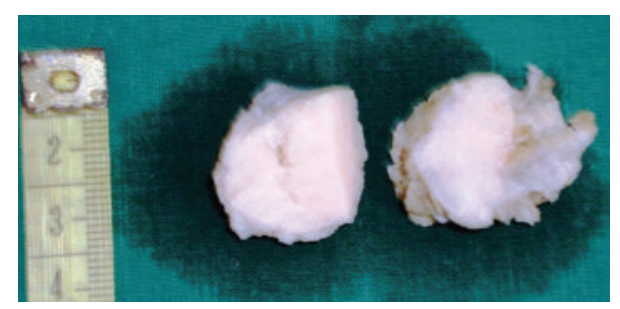

FIGURE 1

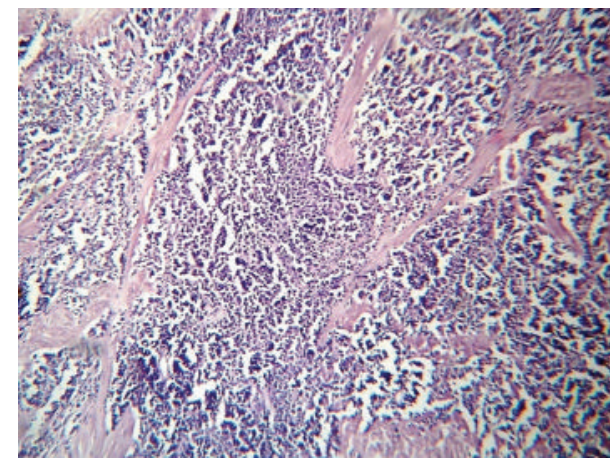

Figure 2

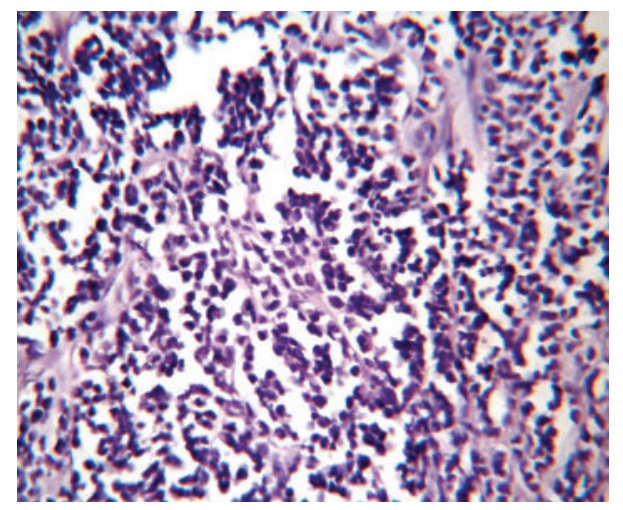

Figure 3

die due to distant metastasis $[1,3]$. There was no association between survival and involvement of a particular vaginal segment or amount of vaginal structure involved with tumor [2]. The tumor can be accepted to be of neuroendocrine character when presence of neuroendocrine granules can be demonstrated on ultrastructural examination or tissue expression of at least two neuroendocrine markers other than neuron-specific enolase (NSE) is detected [7]. Synaptophysin and chromogranin are the principle markers for neuroendocrine tumors [8].

In our case, the patient is 50-year-old postmenopausal female, which is clinicopathologically correlated. Histological findings in our patient are identical to those of pulmonary small cell carcinoma. On the immunohistochemistry (IHC), cytoplasm of tumor cells stained for synaptophysin, chromogranin, and NSE. All these are markers for neuroendocrine tumors $[7,8]$.

Allthough extra pulmonary small cell carcinoma (including genital tract) is recognized as a clinicopathologic entity

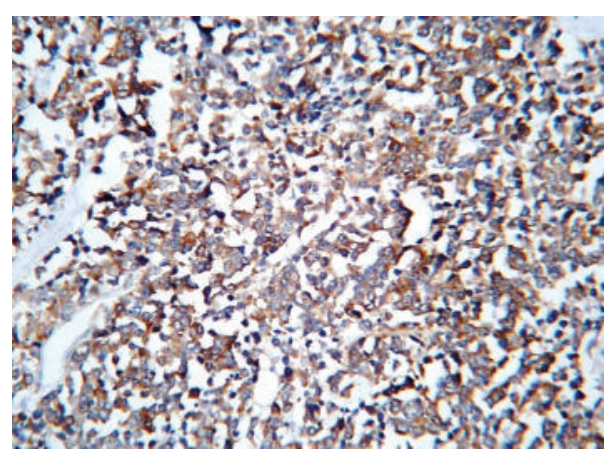

Figure 4

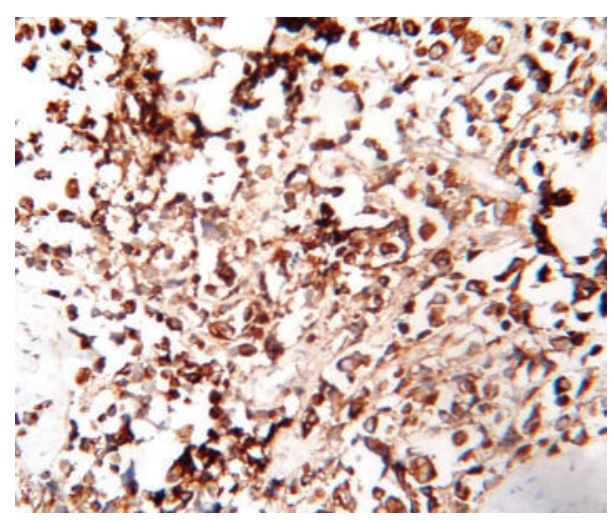

Figure 5

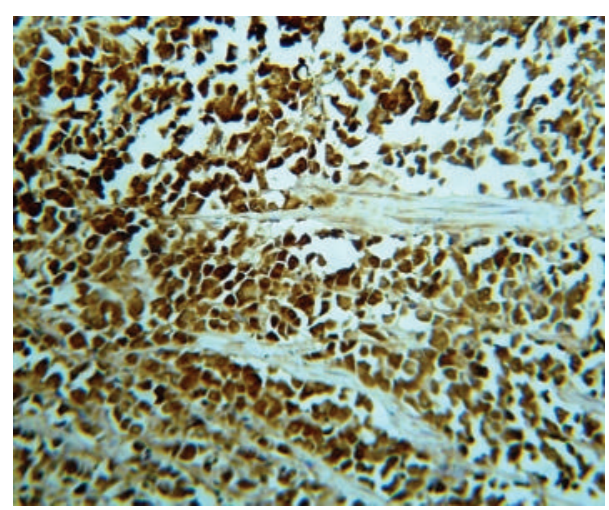

Figure 6

distinct from small cell carcinoma of lung, the aggressive nature of these tumors is similar to that of the pulmonary counterpart $[1,6]$. Current diagnosis of neuroendocrine tumors is significantly improved by the introduction of the chromogranin A (CgA) assay in plasma or serum as a tumor marker, and by the use of somatostatin receptor scintigraphy (SRS) for tumor localization. The SRS proved to be more sensitive than $\mathrm{CgA}$, with equivalent specificity. The plasma CgA level is related to tumor secretory activity [9].

To conclude, primary small cell neuroendocrine carcinoma of vagina is a rare tumor with aggressive behavior and poor prognosis. They exhibit morphological features similar to those of neuroendocrine tumor of both gastrointestinal tract and lung and express neuroendocrine markers. Early 
diagnosis and multimodality therapy are recommended for better survival.

\section{References}

[1] V. Singh, H. Singh, C. Leong, R. Hwang, and W. I. Noguera, "Vaginal small cell carcinoma: case report and review of literature," New York Medical Journal, 2008, http://newyorkmedicaljournal.org/1/Articles/singh4-08.htm.

[2] W. A. Peters III, N. B. Kumar, and G. W. Morley, "Carcinoma of the vagina. Factors influencing treatment outcome," Cancer, vol. 55, no. 4, pp. 892-897, 1985.

[3] C. J. Prasad, J. A. Ray, and S. Kessler, "Primary small cell carcinoma of the vagina arising in a background of atypical adenosis," Cancer, vol. 70, no. 10, pp. 2484-2487, 1992.

[4] Z. Bing, L. Levine, J. A. Lucci, S. S. Hatch, and M. A. Eltorky, "Primary small cell neuroendocrine carcinoma of the vagina: a clinicopathologic study," Archives of Pathology and Laboratory Medicine, vol. 128, no. 8, pp. 857-862, 2004.

[5] W. Chafe, "Neuroepithelial small cell carcinoma of the vagina," Cancer, vol. 64, no. 9, pp. 1948-1951, 1989.

[6] R. E. Joseph, M. H. Enghardt, D. L. Doering, B. F. Brown, D. W. Shaffer, and H. B. Raval, "Small cell neuroendocrine carcinoma of the vagina," Cancer, vol. 70, no. 4, pp. 784-789, 1992.

[7] A. Kasprzak, M. Zabel, and W. Biczysko, "Selected markers (chromogranin A, neuron-specific enolase, synaptophysin, protein gene product 9.5) in diagnosis and prognosis of neuroendocrine pulmonary tumours," Polish Journal of Pathology, vol. 58, no. 1, pp. 23-33, 2007.

[8] R. V. Lloyd, "The neuroendocrine and paracrine system," in Sternberg 's Diagnostic Surgical Pathology, S. E. Mills, D. Carter, V. E. Reuter, J. K. Greenson, M. H. Stoler, and H. A. Oberman, Eds., pp. 507-519, Lippincott Williams \& Wilkins, Philadelphia, $\mathrm{Pa}$, USA, 4th edition, 2004.

[9] M. Dhingra, A. Agarwal, S. Kaushik, and S. N. Singh, "Smallcell neuroendocrine tumor of larynx: a rare presentation," Indian Journal of Pathology and Microbiology, vol. 51, no. 1, pp. 63-64, 2008. 


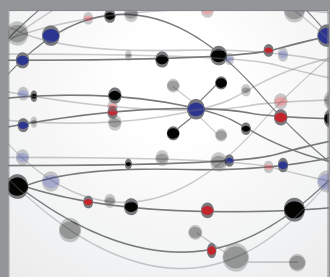

The Scientific World Journal
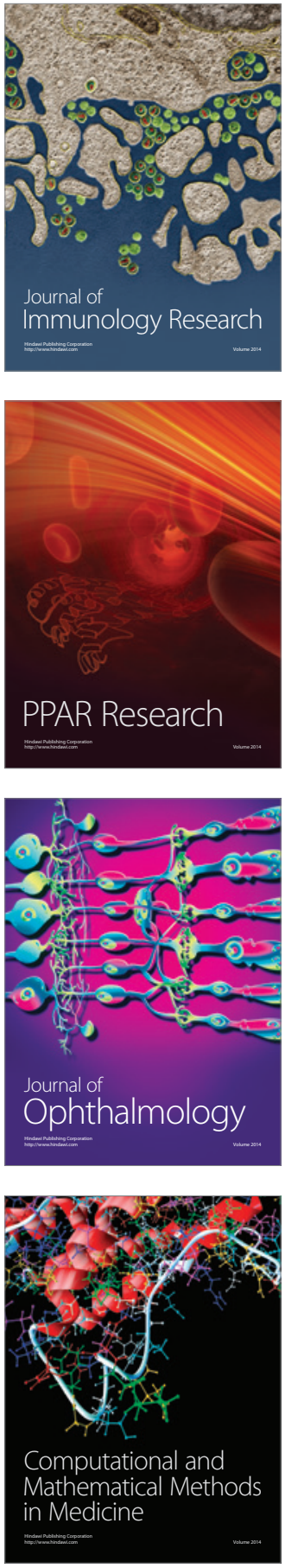

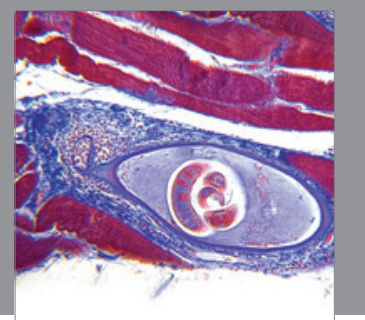

Gastroenterology

Research and Practice
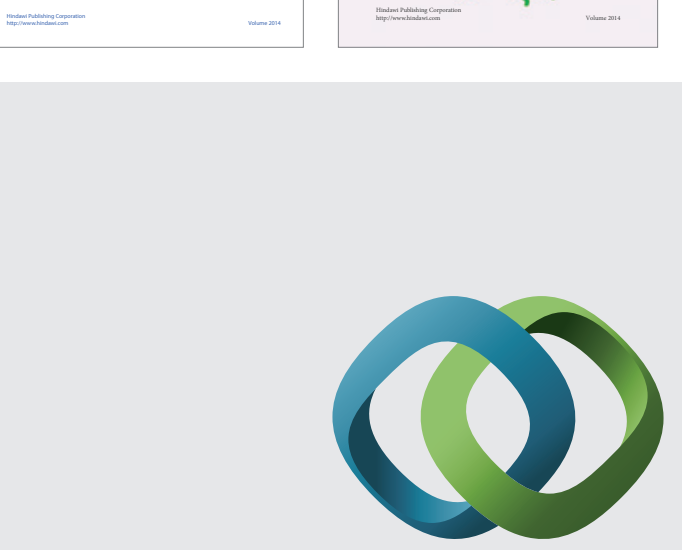

\section{Hindawi}

Submit your manuscripts at

http://www.hindawi.com
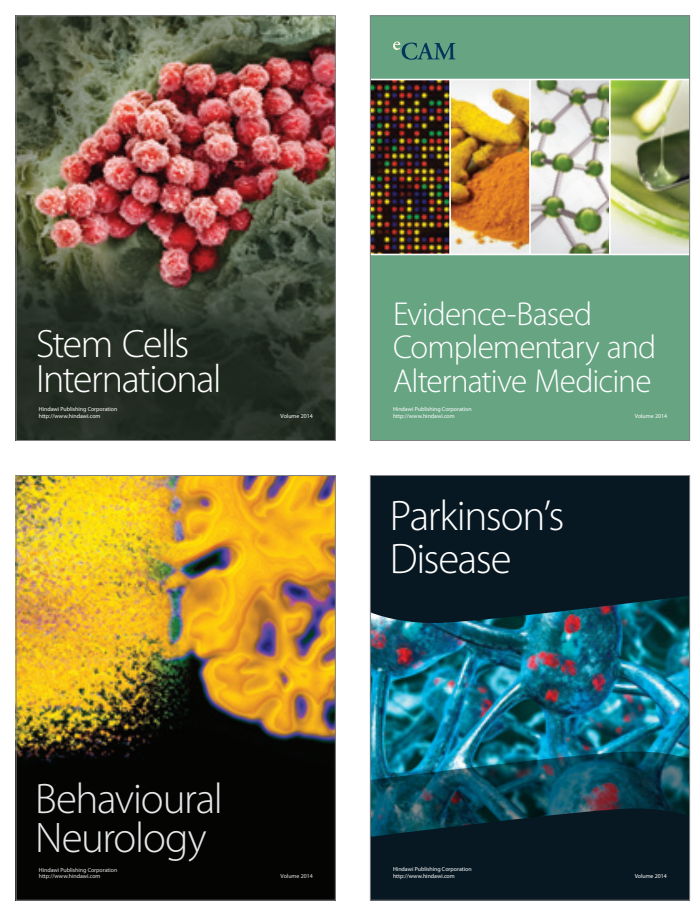

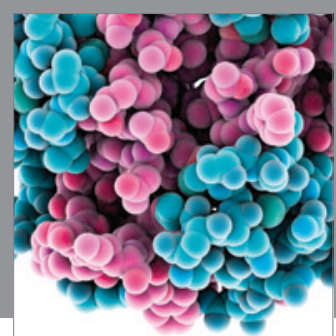

Journal of
Diabetes Research

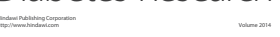

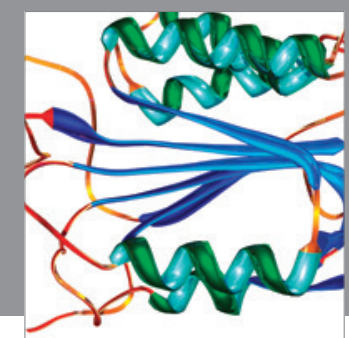

Disease Markers
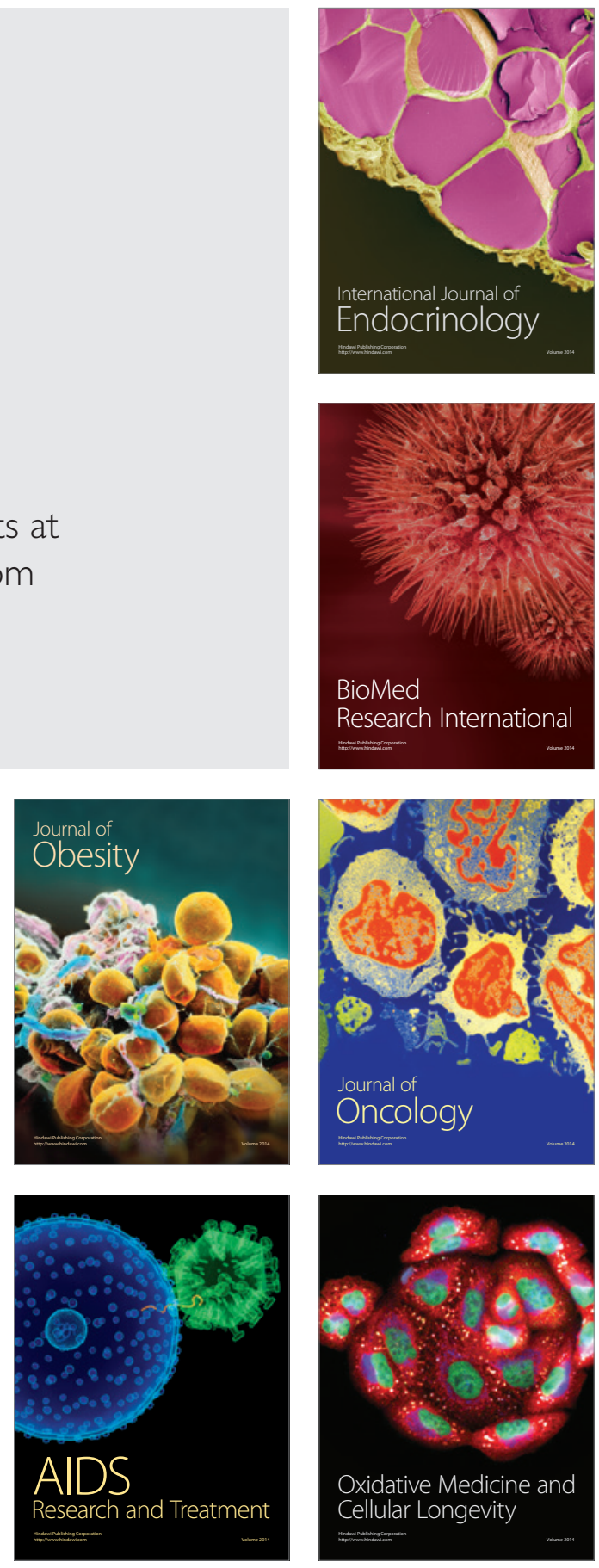